\title{
The challenging management of Rift Valley Fever in humans: literature review of the clinical disease and algorithm proposal
}

\author{
Emilie Javelle ${ }^{1,2^{*}}$, Alexandre Lesueur ${ }^{1}$, Vincent Pommier de Santi ${ }^{2,3}$, Franck de Laval $^{3,4}$, Thibault Lefebvre ${ }^{5}$, \\ Guillaume Holweck', Guillaume André Durand ${ }^{6,7}$, Isabelle Leparc-Goffart ${ }^{6,7}$, Gaëtan Texier ${ }^{2,3}$ \\ and Fabrice Simon ${ }^{1,7}$
}

\begin{abstract}
Rift Valley Fever (RVF) is an emerging zoonotic arbovirus with a complex cycle of transmission that makes difficult the prediction of its expansion. Recent outbreaks outside Africa have led to rediscover the human disease but it remains poorly known. The wide spectrum of acute and delayed manifestations with potential unfavorable outcome much complicate the management of suspected cases and prediction of morbidity and mortality during an outbreak. We reviewed literature data on bio-clinical characteristics and treatments of RVF human illness. We identified gaps in the field and provided a practical algorithm to assist clinicians in the cases assessment, determination of setting of care and prolonged follow-up.
\end{abstract}

Keywords: Rift Valley Fever, Human disease, Management, Algorithm

\section{Background}

Rift Valley Fever virus (RVFV) is an arbovirus, mainly transmitted by mosquitoes, responsible for a zoonosis disease that affects cattle, sheep, camels and goats. It was first identified in 1931 during an investigation into an epidemic among sheep on a farm in the Rift Valley of Kenya [1]. The virus infects also humans through inoculation after contact with infected animals or through ingestion of unpasteurized or uncooked by-products of infected animals, or also through inhalation of aerosols produced during the slaughter of infected animals. However, human infections occurred also from the bites of infected mosquitoes, mainly Aedes and Culex but also Anopheles or Mansonia, and other blood-feeding vectors such as flies and ticks have been identified [2-4]. To date,

*Correspondence: emilie.javelle@gmail.com

${ }^{1}$ Laveran Military Teaching Hospital, CS500413384, Marseille Cedex 13, France

Full list of author information is available at the end of the article no human-to-human transmission of RVFV has been documented.

RVFV belongs to the Phenuiviridae family (formerly Bunyaviridae), member of the phlebovirus genus. The enveloped virion contains a tripartite, predominantly negative-sense, single-stranded RNA genome, which codes for structural and non-structural proteins the virus needs to replicate both in mammalian hosts and insect vectors. RVFV attach to cells via the interaction between the viral structural proteins $\mathrm{Gn}$ and $\mathrm{Gc}$ and C-type lectins, DC-SIGN and I-SIGN [5]. Cells become infected with RVFV by receptor-mediated endocytosis, followed by $\mathrm{pH}$-mediated fusion of virus-endosomal membranes to release nucleocapsids into the cell cytoplasm. Transcription, translation, and genome replication occur in the cytoplasm. The non-structural protein NSs is known to be a major virulence factor allowing the virus to escape host innate immune response. Only one serotype is recognized but strains exist of variable virulence. Moreover, RVFV is classified as a Risk Group 3 agent, and biosafety 
level (BSL)-3 containment requirements are needed to work with the virus in the laboratory [6].

As other arboviral infections including dengue, chikungunya and zika, RVF is emerging worldwide, due to the globalization of arthropod vectors, mainly mosquitoes, which efficiently transmit an increasing number of old, unrecognized and new viruses. Arboviruses pose a major threat of introduction to several continents, including Europe and North America, with the possibility of cocirculation [7]. The widespread presence of competent vectors, the high viral load in infected animals, trade and global travel, all increase the likelihood of RVFV exportation and establishment outside endemic regions [8-10]. Cases have already been imported to Europe and Asia $[9,11,12]$ and concerns have raised about its potential to extend to other parts of Asia, Europe [13] and United States $[14,15]$. Such an introduction would cause significant losses to the livestock industry and substantial human morbidity and mortality [16]. Clinicians need to consider RVF in the differential diagnosis for febrile illnesses in a suitable context, however manifestations of RVFV in humans are varied and unspecific including hepatitis, encephalitis, hemorrhagic disease, and retinitis with potential dramatic consequences. The overall case fatality rate is estimated from 0.5 to $2 \%[8,17]$, but higher mortality rates were recorded, as for example $18 \%$ by the Saudi Health Ministry in 2000 [18], around 22\% in East Africa, West Africa, South Africa and Madagascar from 2006 to 2010 [16], and 28\% in Tanzania in 2007 [19].

In 2019 RVFV emerged in Mayotte, a French overseas department and region and gave growth to this work [20]. Strategies of RVFV control appeared us challenging because of its complex biological cycle and its multiple routes of transmission to humans [21]. Besides, the wide clinical spectrum over a long-period of time made very difficult the establishment of standard definitions of human cases and recommendations for their management. We conducted a literature review on the RVF clinical disease and treatments in humans. We identified the state and frontiers of knowledge. Lacking guidelines on the RVF human disease, we proposed an algorithm to assist physicians on the field in the evaluation of cases. This algorithm could help and be improved during next epidemics.

\section{Methods}

We based on Preferred Reporting Items for Systematic Reviews and Meta-Analyses (PRISMA) guidelines to conduct this clinical review and build the flow diagram (Fig. 1) [22].

We did a literature search for English and French language studies published in electronic databases for an unlimited period until December, 2019: PubMed Central,
Embase, Medline and Scopus. We used the keywords "rift valley fever" and "human". Along with this, we conducted targeted search within the online archives of journals of tropical medicine, which published the first clinical reports of RVF in humans since 1930s, i.e. "South African Medical Journal" and "Transaction of the Royal Society of Tropical Medicine and Hygiene". We contacted editorial office of other journals to get relevant articles published between 1930s and 1990s. If available, we reviewed citations in PubMed of these first articles in literature. Besides, we consulted the databases, datasets and official reports of the World Health Organization (WHO) and the Centre for Disease Control (CDC) on their official websites and the mentioned references.

We removed duplicates and screened titles and abstracts of all these records to include manuscripts reporting clinical descriptions and/or treatments of RVF in humans (case reports and case series). Animal models for RVFV pathogenicity studies published during the last 10 years were also considered. Serological surveys, works on vaccines, immunology, biology, veterinary science and entomology were excluded.

Totally, 129 articles resulting from these searches with full-text available were assessed for eligibility. Among them, 35 with uncertain RVF diagnosis or without significant content or input were removed.

Relevant references cited in the eligible articles were reviewed and other records were manually searched and added for specific purposes of our article using the following terms "Rift Valley Fever" and "severity", "severe", "prognosis", "death", "fatal", "risk factors" and "scores". At the end, 107 articles were referenced in the final review (Fig. 1).

We used data on RVF human cases reported by the WHO in the rubric "disease outbreak news" [23] and the CDC outbreak summaries [24] to build an epidemiological overview and we used the software Adobe Illustrator 22.1 and macrovector official freepik for figures.

\section{Epidemiology}

Human cases have been reported from many African countries following the virus introduction via infected livestock trade [25]. Since the end of 1900s, the virus has extended outside the African continent to Indian Ocean Islands: Madagascar [26], Comoros, and Mayotte [27-29], and has reached the Arabian Peninsula in 2000-2001, with a total estimated 200,000 human infections and 250 deaths in Saudi Arabia and Yemen. During the twenty-first century, outbreaks also occurred in Egypt, Kenya, Somalia, Tanzania, Sudan, Madagascar, the Republic of South Africa, Namibia, Mauritania, Uganda, Niger, and Mayotte (Fig. 2), with fatal cases (Table 1). Recently, RVFV has circulated in Mayotte 


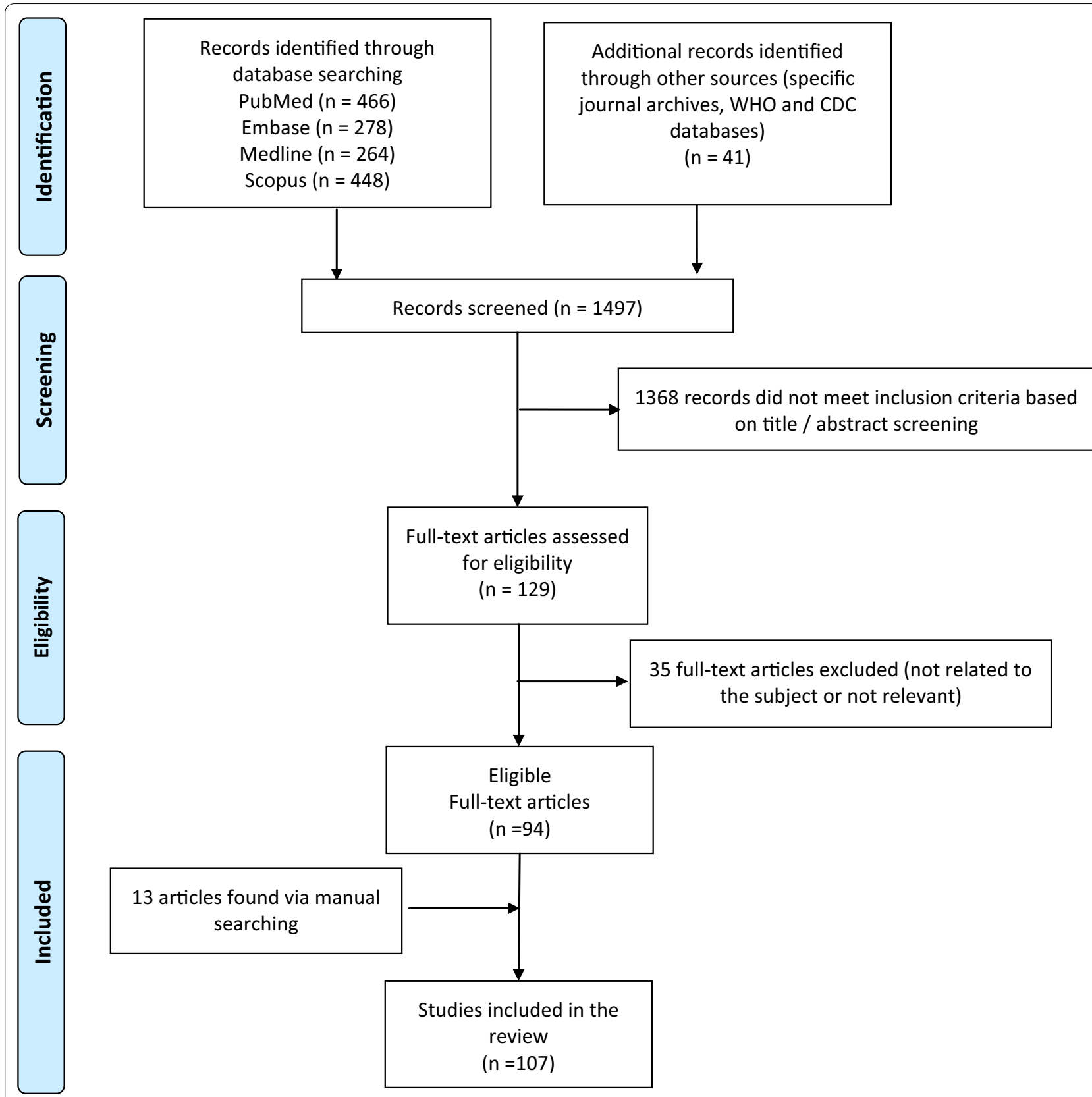

Fig. 1 Literature search and study selection

from November 2018 to August 2019 [30, 31]. Moreover, since September 2019, 365 human cases of RVF have been reported from Sudan, including 11 associated-death (WHO data as of 9 December 2019). The number of secondary cases arising from a single primary case infected with RVFV in an entirely susceptible population, the socalled $R_{0}$, has been estimated 1.19 with a range including 1 [32, 33], but methods used to calculate this basic reproductive ratio have some limits [34].

\section{The typical benign disease}

Infection with RVFV is mostly pauci-symptomatic in humans. General signs may occur in 50 to $95 \%$ of infected cases after an incubation period of 2 to 6 days. The typical presentation includes headache, fever, backache and generalized aches in muscles and joints, lasting 4 to 7 days $[4,17,35,36]$. Malaise, anorexia, nausea, vomiting, flushed face, and conjunctival suffusion were 


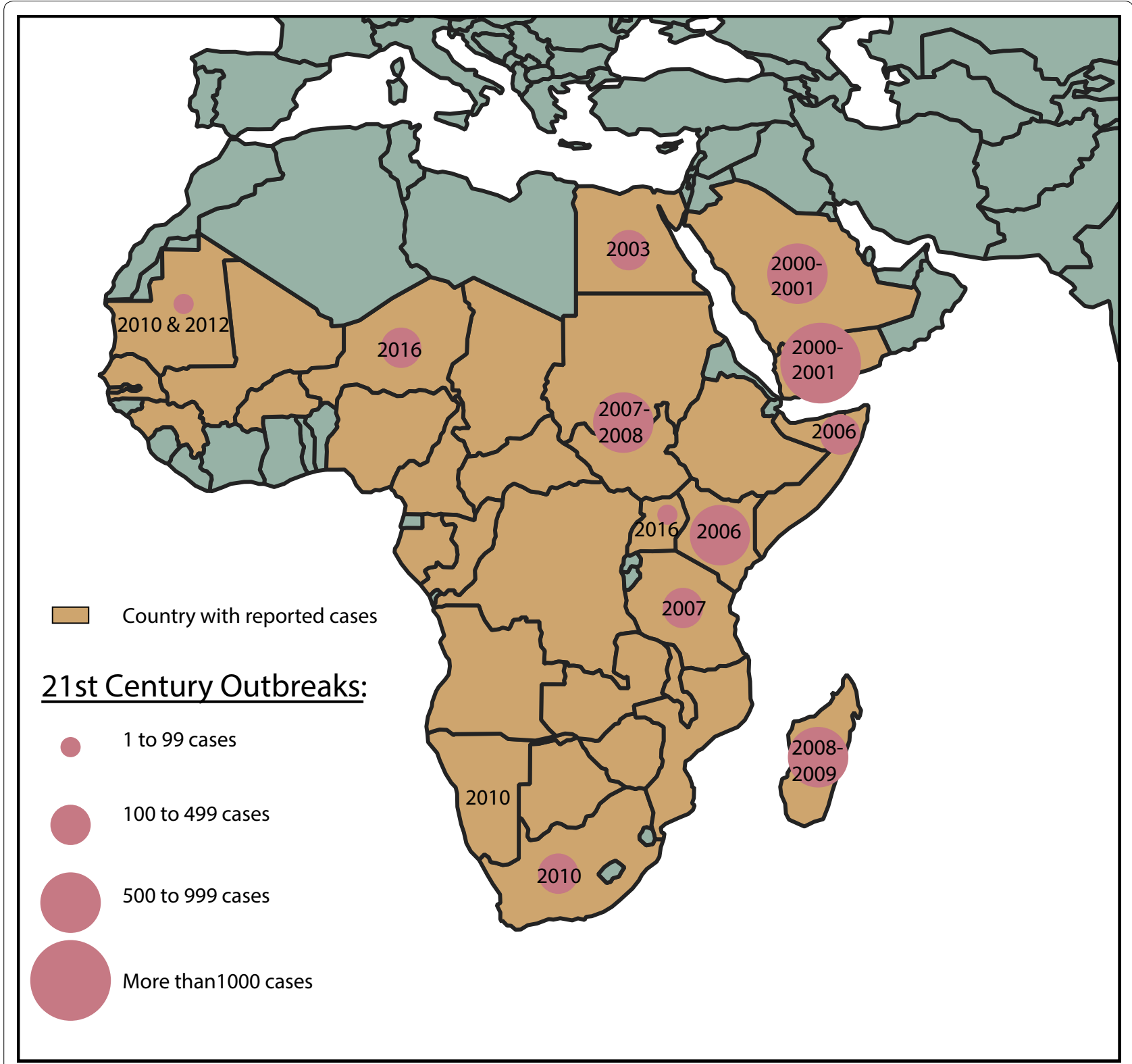

Fig. 2 Rift Valley Fever distribution: endemic countries and recent outbreaks since 2000

also reported [17, 37]. RVF differs from influenza, dengue and chikungunya as to whether cough, skin involvement (i.e. rash or pruritus) and arthritis are respectively uncommon signs. A slight meningism at the acute stage is not rare, however its prognosis value has never been evaluated [37]. Basically, retro-orbital pains and neck stiffness are features hard to classify because both of them were commonly reported in uncomplicated RVF cases [36], but were also associated with the occurrence of complications [37, 38].

\section{Complicated and severe expression}

Incidences of complications are uncertain because RVFV infection can go unrecognized or be misdiagnosed considering the unspecific symptoms of suspected cases, which overlap with many other co-circulating pathogens [39]. No standard definition of suspected cases exists. Rates of complications measured in studies depend on the definitions and methods of recruitment. Indeed, the use of clinical or biological criteria specific to RVF complications to define suspected cases could lead to underestimate the mild forms [40-42]. Globally, since the first 
Table 1 Major Rift Valley Fever outbreaks with cumulated reported human cases and confirmed deaths over the period 2000-2019 (WHO data [23])

\begin{tabular}{|c|c|c|c|c|c|}
\hline Outbreaks dates & Geographic distribution & Reported cases & $\begin{array}{l}\text { Cumulated reported } \\
\text { cases }\end{array}$ & $\begin{array}{l}\text { Deaths } \\
\text { confirmed }\end{array}$ & $\begin{array}{l}\text { Cumulated } \\
\text { confirmed } \\
\text { deaths }\end{array}$ \\
\hline 2000-2001 & Saudi Arabia, Yemen & 886 & 886 & 123 & 123 \\
\hline $2006-2007$ & Kenya & 700 & 1586 & 158 & 281 \\
\hline $2006-2007$ & Somalia & 114 & 1700 & 51 & 332 \\
\hline $2006-2007$ & Tanzania & 264 & 1964 & 109 & 441 \\
\hline 2007-2008 & Sudan & 747 & 2711 & 230 & 671 \\
\hline 2008-2009 & Madagascar & 712 & 3423 & 26 & 697 \\
\hline 2009-2011 & South Africa and Namibia & $>250$ & 3673 & 26 & 723 \\
\hline 2010 & Mauritania & 63 & 3736 & 13 & 736 \\
\hline 2012 & Mauritania & 41 & 3777 & 18 & 754 \\
\hline 2013-2014 & Mauritania and Senegal & 11 & 3788 & 0 & 754 \\
\hline 2015 & Mauritania & 31 & 3819 & 8 & 762 \\
\hline 2016-2018 & Uganda & 16 & 3835 & 7 & 769 \\
\hline 2016 & Niger & 348 & 4183 & 33 & 802 \\
\hline 2018 & Kenya & 26 & 4209 & 6 & 808 \\
\hline 2019 & Mayotte & 143 & 4352 & 0 & 808 \\
\hline $2019-\ldots{ }^{a}$ & Sudan ${ }^{\mathrm{a}}$ & $365^{a}$ & 4717 & $11^{\mathrm{a}}$ & 819 \\
\hline
\end{tabular}

a Ongoing outbreak, provisional figures from reports as of 9th December 2019

description of the spectrum of RVF in humans by Laughlin et al. during the major outbreak in Egypt in 1977, it is considered that less than $5 \%$ of symptomatic cases will present complications including ocular, neurologic and hemorrhagic symptoms, while favorable outcome will occur within 1 week for the others [17]. In this historical series, the different known complications occurred in equal proportions (30-35\%), but hepatic or renal failures were not identified. During the 2007 Kenyan outbreak, Kahlon et al. described a clinical syndrome suggestive of severe RVF, characterized by fever, large-joint arthralgia, and gastrointestinal complaints, later followed by jaundice, right upper-quadrant pain, and delirium, often coinciding with hemorrhagic manifestations [43]. Complicated forms could have represented up to $20 \%$ of symptomatic cases during recent epidemics [36].

Morbidity, as well as mortality, varied from one to another outbreak. For example, in South Africa in 1975 [44] and in Tanzania in 2007 [19] most of RVF severe cases presented with encephalopathy (respectively $71 \%$ and $89 \%$ ), whereas hemorrhagic manifestations predominated in Mauritania in 2015 (81\%) [45] and Madagascar in 2008 (88\%) [46]. In Saudi Arabia in 2000, hepatic insufficiency $(75 \%)$ and renal failures $(41 \%)$ were the most frequent complications [47]. Moreover, during the epidemic in Madagascar, highly fatal associations of two or more complications were highlighted. These occurred in 11/16 (69\%) severe cases, of whom 5 (45\%) had encephalitis with hemorrhagic symptoms which were lethal in $2 / 5$
(40\%), representing half of the deaths (4/16) [46]. Variations in the RVFV tropism and virulence are hypothesized according to the lineage involved and the possible accumulation of genetic mutations or genomic reassortments [17, 48-50], despite a low overall genomic diversity $(\sim 5 \%)$ at the nucleotide level [51]. Genetic, ethnic or epidemiologic factors in the population exposed to the virus, as well as access to care also play a role $[17,52]$.

Manifestations of RVF in humans are represented in Fig. 3. Alternative diagnoses concern a broad array of conditions which may be worldwide distributed or restricted to endemic areas. Characteristics and differential diagnoses of RVF manifestations are summed-up in Table 2.

\section{Risk factors for severe disease}

Determinants for severe RVF outcome are poorly known. A number of retrospective studies suggest that touching, handling, living close to, and consuming animal products are factors associated with increased likelihood of RVF virus infection and possibly more severe outcomes [19, 53]. This is probably linked with a significant exposure to the virus that results in higher inoculation rate. Indeed viremic loads have been reported correlated with severe RVF diseases [54]. Single nucleotide polymorphisms (TLR3, TLR7, TLR8, MyD88, TRIF, MAVS, and RIG-I) were also associated with severe symptomatology [55]. Acute malaria co-occurrence was observed in severe forms and HIV-positive status was associated with a $75 \%$ 


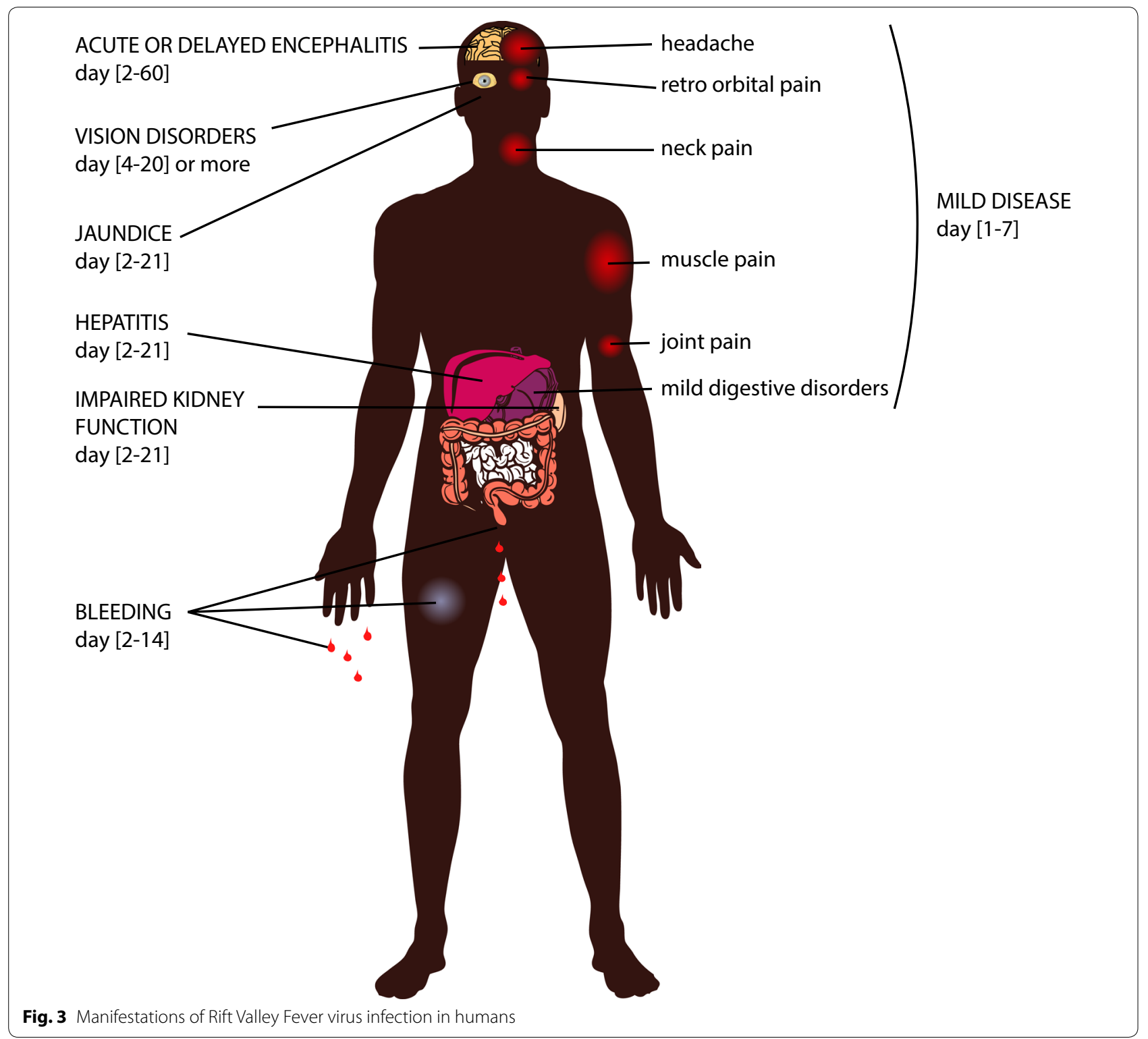

case fatality rate in Tanzania in 2007 [19]. Schistosomal liver co-involvement and bacterial or fungal co-infections were also documented in fatal cases [37].

\section{Hepatic manifestations}

Liver is the primary site of RVFV replication, so that it is frequently early involved during RVFV acute infection [56, 57]. A severe acute hepatotropic disease may occur with liver failure and jaundice within the first 3 weeks of the disease [43]. Tenderness, palpable enlargement and more than threefold elevation in transaminases are criteria of severity $[42,58]$. Jaundice was proved to be independently associated with a high mortality rate [40]. Acute hepatitis may complicate with prolonged blood coagulation times and may occur together with or precede fatal hemorrhages or neurologic complications. Autopsy studies and pathogenesis characterization in mouse model found evidence of liver necrosis with RVF viral antigens identified within hepatocytes and Küpffer cells, arguing for a direct virus-induced cellular necrosis $[19,37,44,57,59,60]$.

A RVF case with a co-existing condition of cirrhosis after hepatitis B infection died as a result of gastrointestinal bleeding and hepatic encephalitis in Mayotte [28], and 4/31 (13\%) severe cases described during the epidemic in Mauritania in 2015 had chronic hepatitis B [61], suggesting that patients with chronic hepatic 
Table 2 Characteristics and alternative diagnoses of Rift Valley Fever manifestations

\begin{tabular}{|c|c|c|c|c|c|}
\hline RVF manifestations & Time of onset & Frequency & Lethality & Sequelae & $\begin{array}{l}\text { Differential infectious } \\
\text { diagnoses }\end{array}$ \\
\hline Influenza-like syndrome & 2 to 6 days of incubation & $50-90 \%$ of infected people & - & Prolonged asthenia & $\begin{array}{l}\text { Arboviruses, influenza virus, } \\
\text { HIV (primary infection) } \\
\text { Rickettsia spp., Coxiella burnetii, } \\
\text { Salmonella spp., bacterial } \\
\text { sepsis } \\
\text { Malarial parasites }\end{array}$ \\
\hline Acute hepatitis & Day 2-21 & $1-2 \%$ of symptomatic cases & $\begin{array}{l}\text { High in } \\
\text { icteric } \\
\text { hepatitis }\end{array}$ & None & $\begin{array}{l}\text { EBV, CMV, HIV, hepatitis viruses } \\
\text { A, B, C, D, E, arboviruses } \\
\text { (yellow fever, dengue, } \\
\text { chikungunya) } \\
\text { Mycoplasma, Leptospirosa } \\
\text { spp., Coxiella burnetii, } \\
\text { Brucella, Bartonella, Babesia, } \\
\text { Pneumococcus, Clostridium } \\
\text { perfringens } \\
\text { Malarial parasites }\end{array}$ \\
\hline Hemorrhagic fever & Day 2-14 (day 2-4) & $\begin{array}{l}1-25 \% \text { of symptomatic } \\
\text { cases }\end{array}$ & $25-65 \%$ & None & $\begin{array}{l}\text { Hemorrhagic viral fevers, } \\
\text { Leptospira spp. }\end{array}$ \\
\hline Ocular signs & Day 4-20 & $\begin{array}{l}0.5-15 \% \text { of symptomatic } \\
\text { cases }\end{array}$ & - & Reduced or lost vision & $\begin{array}{l}\text { Measles, rubella, influenza, } \\
\text { CMV, HSV, VZV, West Nile, } \\
\text { chikungunya, dengue and } \\
\text { various encephalitis viruses } \\
\text { Rickettsia spp., Borrelia burg- } \\
\text { dorferi, Treponema pallidum }\end{array}$ \\
\hline Acute encephalitis & Day 2-10 & $<1 \%$ of symptomatic cases & $50 \%$ & Neurologic disorders & \multirow[b]{2}{*}{$\begin{array}{l}\text { Enteroviruses, measles, } \\
\text { mumps, rubella, influenza, } \\
\text { rabies viruses, arboviruses } \\
\text { (West-Nile, dengue, regional } \\
\text { encephalitis), HIV } \\
\text { Listeria, Rickettsia, Treponema } \\
\text { pallidum, Brucella, Borrelia, } \\
\text { Leptospirosa spp., Chlamydia, } \\
\text { Mycoplasma, 土bacterial } \\
\text { meningitis (meningococcal, } \\
\text { pneumococcal) } \\
\text { Plasmodium falciparum, } \\
\text { Trypanosoma spp., Toxo- } \\
\text { plasma gondii, Echinococcus, } \\
\text { Cryptococcus, Histoplasma } \\
\text { capsulatum }\end{array}$} \\
\hline Delayed encephalitis & Day 4- 60 & $1-5 \%$ of symptomatic cases & $<50 \%$ & Neurologic disorders & \\
\hline
\end{tabular}

HIV human immunodeficiency virus, EBV Epstein Barr virus, CMV cytomegalovirus, HSV herpes simplex viruses, VZV varicella zoster virus

disorders-mainly hepatitis B chronic infection-could be at higher risk of unfavorable outcome.

\section{Hemorrhagic fever}

Soon after the onset of flu-like illness or acute hepatitis, patients may present bleeding from the nose or gums (gingivorrhagia being a key early warning sign) [62], hematemesis or melaena, petechial/purpuric rash or ecchymoses, menorrhagia, hematuria, or bleeding from venipuncture sites $[46,63]$. Yellow fever-like expression were also reported with a first improvement at day 3 followed by a rebound of fever [62]. Epistaxis is not considered a reliable sign of how serious the illness is $[64,65]$. Thrombocytopenia is invariably present. Hepato-renal failure with jaundice, disseminated intravascular coagulation and encephalitis can be associated $[44,66]$. Overall prevalence is estimated $1 \%$, but prevalence was rather $10 \%$ in hospital cohorts [40, 47]. A population-based survey during the 2007 outbreak in Kenya even reported $26 \%$ of hemorrhagic RVF disease with a mortality of $23 \%$ in this group of cases [67]. Indeed, the mortality rate associated with bleeding manifestations is the highest, up to $65 \%$ [40,68]. Viral load could play an important role in the hemorrhagic expression. In humans studies, it exhibited positive correlation with markers of inflammation (IP-10, CRP, Eotaxin, MCP-2 and Granzyme B), markers of fibrinolysis (tPA and D-dimer), and markers of endothelial function (sICAM-1), but a negative correlation with P-selectin, ADAMTS13, and fibrinogen, which are 
associated with coagulation pathways occurring on the endothelial surface [69].

\section{Meningoencephalitis}

The onset of meningoencephalitis usually occurs 1 to 4 weeks after the first symptoms (which may be very mild or subclinical), and in some cases neurological complications can manifest beyond 60 days after the initial symptoms of RVF. Clinical features may include intense headache, neurological deficit, rigor, neck rigidity, hyperreflexia, hypersalivation, choreiform movements, loss of memory, hallucinations, confusion, disorientation, vertigo, convulsions, ataxia, lethargy, decerebrate posturing, locked-in syndrome and coma [17, 35, 44, 70-73]. In a human outbreak in Mauritania in 1989, up to 5\% of observed infections had encephalitis [71]. Two types of pure encephalitis were described: acute febrile forms with short duration and possibility of death, and subacute forms with a longer duration, a lower fatality rate but frequent sequelae [71]. Pulmonary complications may occur $[71,74]$, and malaria can worsen the severity of neurologic symptoms [19]. Lethality may be as high as $50 \%$ in this form [40].

From Mauritania in 1989, clear a cellular CSF were documented in all cases with encephalitis [71]. In a 18-year old woman treated for chronic myeloid leukemia with acute RVFV encephalitis acquired in Saudi Arabia, CSF was documented predominantly with polynuclear leukocytes. Magnetic resonance imaging (MRI) showed high signal intensity on T2-weighted images in frontoparietal and thalamic regions, with multiple bilateral asymmetrical cortical hyperintense areas consistent with inflammation or ischemia in axial diffusion, while changes in CT-scan of her brain appeared much later [70]. In delayed meningoencephalitis normal glucose and protein concentrations will lymphocytic pleocytosis were found in CSF [17]. In a kidney transplant recipient with cured hepatitis B, presenting acute hepatitis followed by delayed pachymeningitis, specific RVF-IgM were detected in lymphocytic CSF at day 58, while IgG were positive in blood at the first screening at day 44 [74], which was consistent with the first neurologic description in literature [72].

In a mouse model of RVF infection, survivors to primarily hepatitis cleared the virus from liver and blood, but exhibited neuro-invasion and fatal encephalitis [57]. Active viral replication in brain leading to necrotizing encephalitis was documented in several animal models $[75,76]$. The route of transmission and prompt robust immune response could be a determining factor of the RVF neurologic disease course [77]. Indeed, whatever the routes of inoculation, RVFV RNA was detected in the brain of infected rats confirming the virus neurotropism
[78], but aerosol exposure to RVFV caused earlier and more severe neuropathology in the murine model and fatal encephalitis in primates $[75,76]$. In aerosol-infected rats with lethal encephalitis, neutrophils and macrophages were the major cell types infiltrating the CNS, and this was concomitant with microglia activation and extensive cytokine inflammation [78]. Differences in the peripheral blood biomarkers during the course of the neurological disease in African green monkeys were measured with defect in early T-cells, proinflammatory and antiviral responses in lethal encephalitis [79]. Other immune disorders and alteration in vascular permeability in the brain could be more involved in delayed forms [80].

\section{Other organic failures}

During RVFV infection, elevated urea and creatinine levels may be secondary to hypovolemia, multipleorgan dysfunction, or hepatorenal syndrome [39, 81]. Acute hepatonephritis, possibly related to direct RVFV injury, characterized by proteinuria and oliguria were also reported with a bad prognosis [62]. In Mauritania in 2015 , creatininemia was meanly more than fourfold upper the reference range in severe cases [61]. In Saudi Arabia in 2000, renal impairment concerned up to $60 \%$ of RVF inpatients and dialysis was needed in $90 \%$ of them [81]. The mortality rate was $31 \%$ in patients with acute renal failure, $25 \%$ in those with hepatorenal syndrome, and $31 \%$ in patients with primary hepatic involvement and mild renal impairment [81]. Progression to chronic renal failure was not seen $[40,47,81]$.

In 2008 in Mayotte, an acute pericarditis with symptoms of right-sided heart failure, relapsing at 1 month, was documented in a 53-year old farmer diagnosed with RVFV infection [28]. In historical post-mortem examinations, fragmentation in myocardial muscle was found in two cases and RVFV was isolated from one pericardial fluid $[37,44]$.

\section{Ocular complications}

Macular exudates with potential permanent loss of central visual acuity were firstly described in 7 among 20,000 estimated cases $(<0.05 \%)$ during the $1950-51$ outbreak in South Africa [82, 83]. The prevalence of ocular manifestations has been estimated to $1 \%$ during epidemic outbreaks in Egypt in 1977, and up to $15 \%$ both in patients with mild and severe RVF disease during the 2000 outbreak in southwest Saudi Arabia [84]. Unilateral or bilateral symptoms generally occur 5 to 14 days after the RVFV infection, but can be more delayed, and may include decreased visual acuity, scotoma, acute hemorrhagic conjunctivitis and retro-orbital pain [85]. The most frequent and most specific ocular lesion is a macular or 
paramacular retinitis $[86,87]$. The funduscopy by indirect ophthalmoscopy usually shows a single well demarcated necrotic lesion with ill-defined creamy-white patchy lesions of macular retinitis with hemorrhages [84]. The other retinal signs include arterial occlusions, vasculitis (mostly phlebitis and sometimes arteritis) [84], sheathing of the vessels, which are best explored using fluorescein angiography. In series, vitreous reaction with vitreal haze or vitritis occurred in less than one third of patients, optic-nerve head edema or palor were described in 15\% of cases with retinal involvement, and no infectious optic neuropathy was reported [84, 85]. Anterior uveitis was associated with a posterior uveitis, defining a panuveitis with aqueous flare and fine non-granulomatous keratic precipitates $[84,85]$. Fluorescein angiography performed during the active phase of the disease may show early hypofluorescence with delayed filling of the arterioles and venules, associated with late staining of the lesions [84]. It also helps for the diagnosis of vasculitis, showing vessels sheathing and staining, and vascular occlusions when present. Follow-up fluorescein angiography performed several months after RVF diagnosis have revealed window defect in the area of the retinitis, vascular occlusions and obliterated macular vessels [84]. However, ophthalmoscopic and angiographic features of the RVFV associated retinitis are not specific and can be encountered in several viral or bacterial infections (Table 3) [85, 87-89].

Ocular active lesions resolve spontaneously in 10 to 12 weeks. Macular or paramacular scarring, vascular occlusions and post-infectious optic atrophy associated to the central scarring lead to poor visual acuity outcomes. Retinal complications may cause $40-50 \%$ of permanent vision loss, and up to $71 \%$ of the affected eyes reached the criteria for legal blindness [38, 84, 85]. No chronic anterior uveitis, posterior synechiae, iris nodules, uveitic glaucoma nor cataract were described [38, $84,85]$. It is not known if the ocular manifestations of the RVF result from direct toxicity of the virus or from an immune response to the infection. Post-mortem examination suggested the presence of focal areas of retinal necrosis and retinal pigment epithelium (RPE) degeneration with round cell inflammatory infiltration and perivascular cuffing but the presence of the virus in the ocular tissues has not been proved. Most of animal models for RVF do not show any ocular disease $[35,57]$. In a sheep model quantitative RT-PCR (qRT-PCR) was positive on eye tissues after the viremic phase [90], but retinal complications of RVF could also be caused by antibodyrelated auto-immune reactions [86].

\section{Congenital and neonatal infection}

In a seroprevalence study, mothers experiencing fetal death or miscarriage had the same RVFV antibody prevalence as those with normal deliveries [91]. A retrospective study in Egypt in 1980 found no increase in the risk of abortion in humans [92]. However a recent cross sectional study has demonstrated an association between infection with RVFV and miscarriage in Sudanese pregnant women $(54 \%$ versus $12 \%$ of risk in non-infected pregnant women with $p<0.0001$ and OR 7.4 with $95 \%$ CI [2.7-20.1] in multiple logistic regression analysis) [93]. The teratogenic potential of the RVFV is unknown. Occasional vertical transmission has been reported, sometimes with fatal outcome in the newborn [94, 95]. Few symptomatic infections were described in pregnant women [91] and children under the age of 10 years old $[96,97]$. The question is remaining whether it is the result of a lack of exposure to infected mosquitoes and infected animals, or if there are differences in susceptibility between animals and humans [8].

\section{Infection prevention and control (IPC) measures}

Importantly, hemorrhagic complications require high cautious infection control measures, following the CDC guidance on infection control precautions for hemorrhagic viral fevers (HVFs), while waiting for the exclusion of other HVFs such as Ebola virus disease or CrimeanCongo hemorrhagic fever $[39,98]$. Standard precautions with Personal Protective Equipment (PPE) were reported sufficient to prevent from nosocomial transmission of RVFV during the outbreak in Arabian Peninsula [99], and must be implemented according the WHO checklist [100], to care any suspected case regarding the theoretic risk of RVFV transmission through contact with infected blood, tissues, or other body fluids, secretions and excretions. Considering RVF is also mosquito-borne disease [56], we recommend for all-day preventive measures against vectors using physical (long clothing and bed nets), chemical (topical repellents and insecticide impregnations) barriers in the environment of viremic patients. Considering the mean length of the viremia, these measures could be reasonably stopped 1 week after the illness onset, but there is no evidence-based cut-off time to allow donation of blood and removal of tissue or organs for transplantation from a RVFV-infected patient.

\section{Virologic confirmation of Rift Valley Fever diagnosis Collection of specimens}

Samples of suspected cases must be collected with PPE and safe handled adhering to BSL-3 precautions. Specimens must be labelled, packaged in accordance with the guidelines for the transport of dangerous biological goods (triple packaging), stored at $4{ }^{\circ} \mathrm{C}$ and addressed to a reference center. If necessary, whole-blood specimens can be dried on blotting paper, stored 30-60 days and 


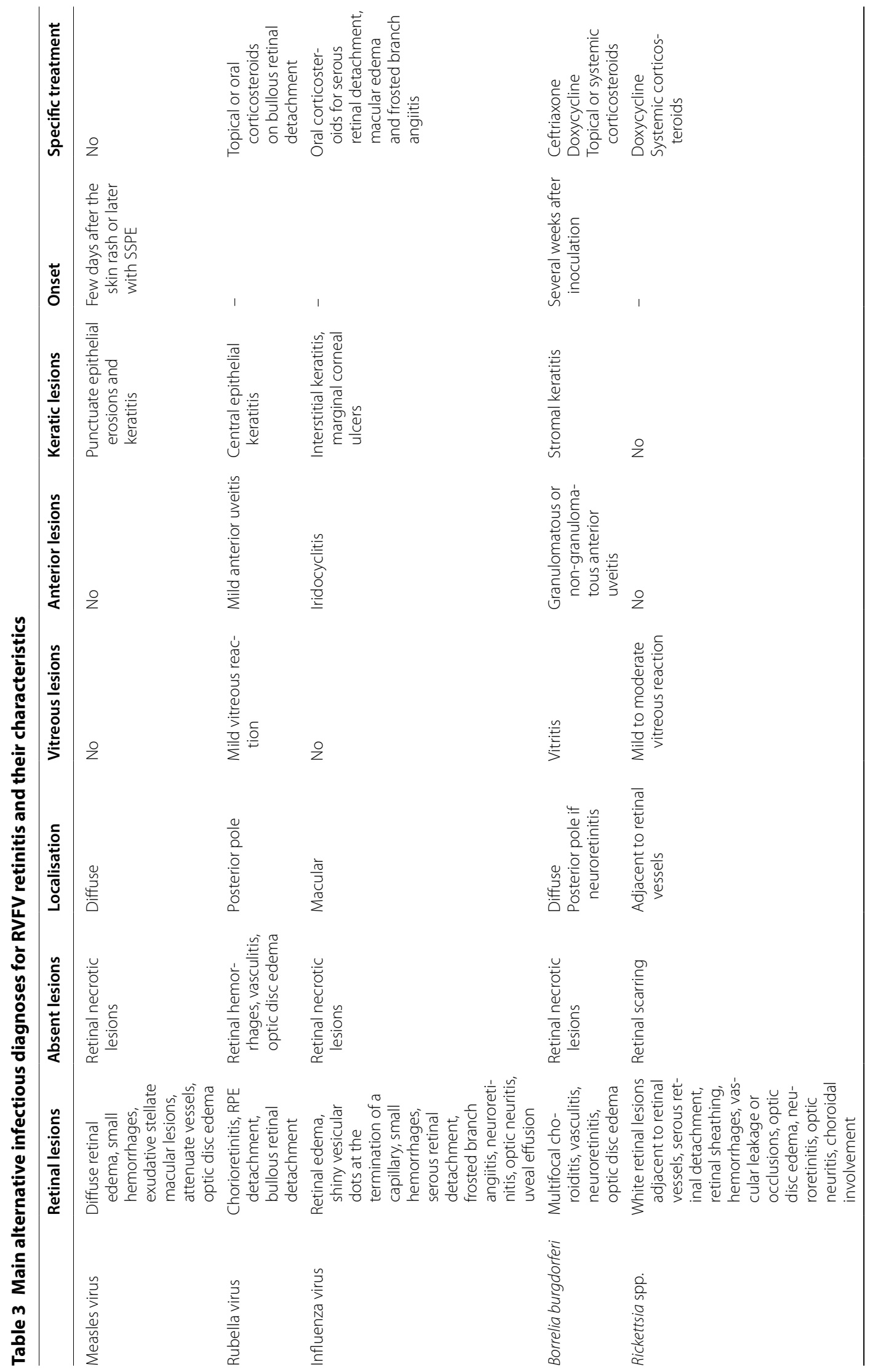




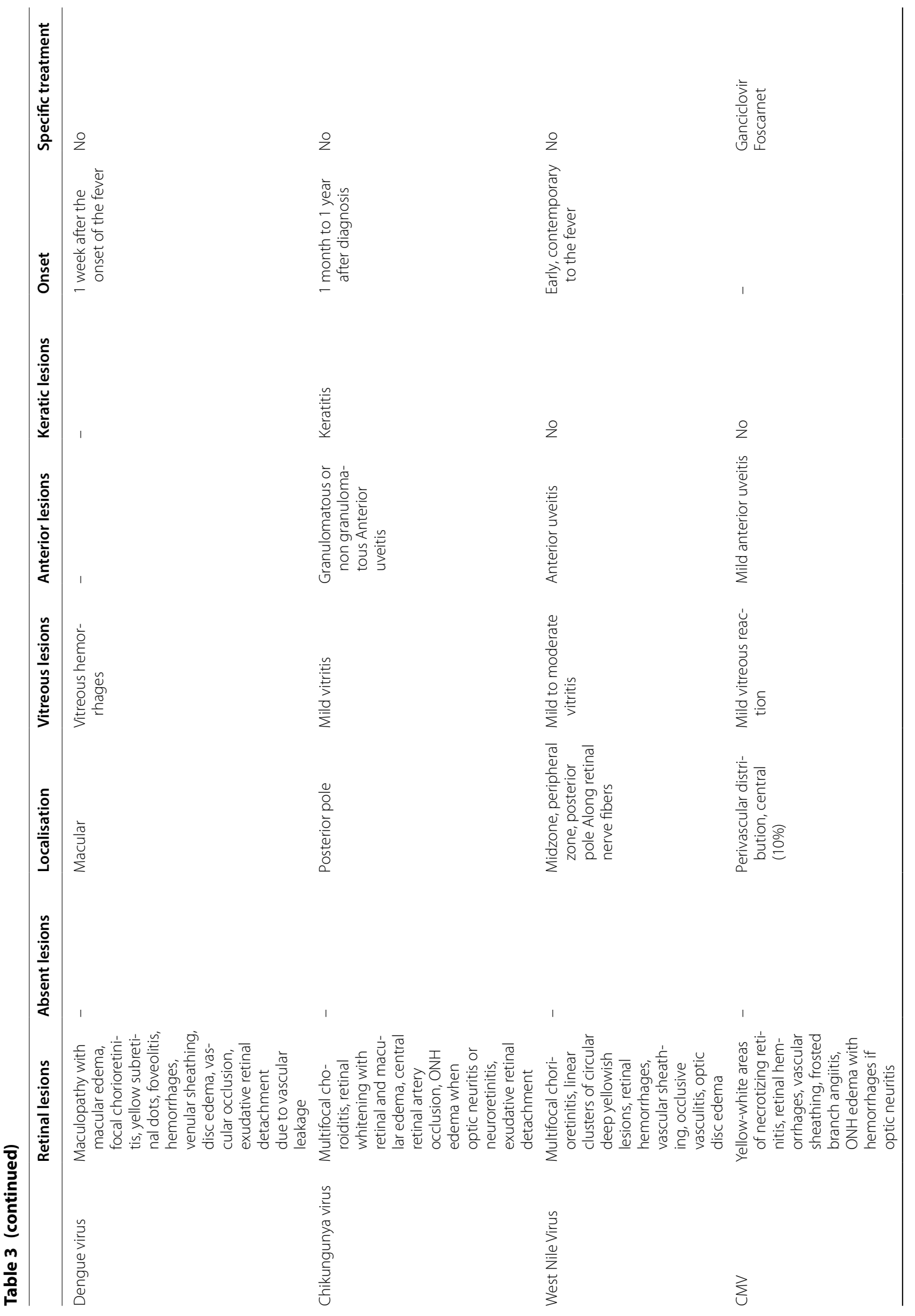




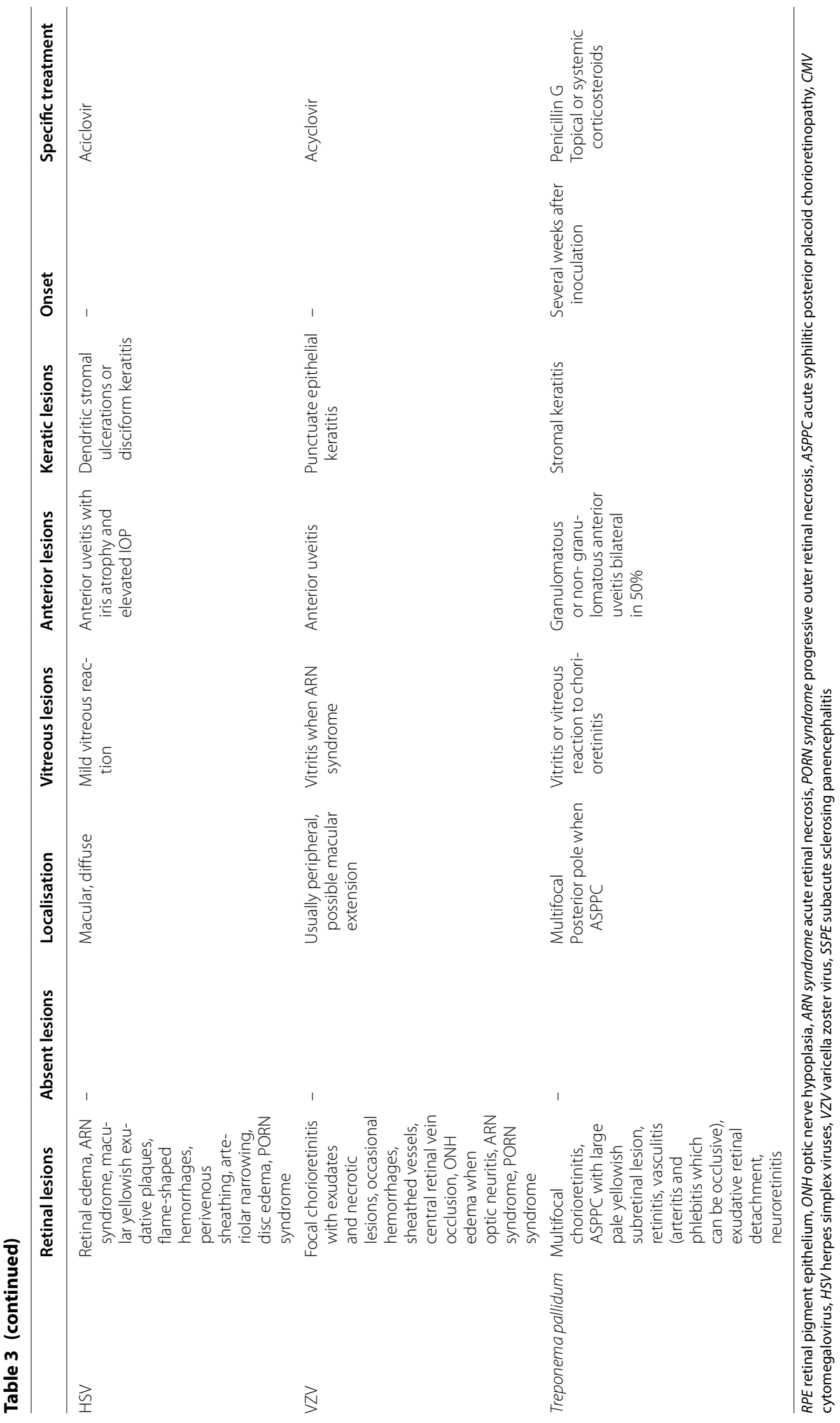


transported without refrigeration for retrospective diagnosis confirmation [9].

\section{Diagnostic testing}

According to WHO a confirmed RVF infection relies on (i) detection of RVFV RNA by reverse transcriptasepolymerase chain reaction (RT-PCR) on sera or plasma; (ii) IgM and IgG detection by enzyme-linked immunosorbent assay (ELISA). Viral isolation is also an assay for laboratory confirmation of RVFV infection but this assay needs to be done on BSL3 and is less sensitive than detection of viral RNA by RT-PCR. Interestingly, RT-PCR for RVFV was reported positive for a prolonged period in urines, semen [74] and whole blood [9]. The RVFV RNA load in blood usually decreases between days 1 to 4 and may be detectable until day 8 after the onset of symptoms [9]. Prolonged and intense viremias were reported during acute encephalitis and hemorrhagic fever. Thus, testing of serial patient specimens collected 24 to $48 \mathrm{~h}$ apart may have prognostic value in determining patient outcome. The decrease in viral loads coincides with a rise in RVFV specific IgM and IgG antibodies that may be testing using ELISA. The presence of IgM antibodies appears as an early transient response (day 4 to 60 ) and protective IgG antibodies persist for several years [36]. A second convalescent blood sample collected 7-14 days after the first is necessary to confirm the seroconversion making a definitive diagnosis of a recent RVF infection.

In case of delayed-onset of encephalitis or ocular complications, imputation to RVFV may be difficult if only IgG are identified in blood at this stage. In human cases with encephalitis, specific IgM and IgG can be detected in CSF $[72,74]$. No positive RVFV cultures or RT-PCR have been reported in CSF, or on aqueous or vitreous samples and should be further tested.

\section{Treatment of RVF cases}

Management of RVF human cases comprises IPC measure implementation and general supportive therapy. No specific treatment is currently available. Iatrogenic use of medications such as hepatotoxic analgesics (acetaminophen), aspirin or non-steroid anti-inflammatory drugs, which enhance the risk of hemorrhagic complications, must be avoided in the early stage. Co-infections or alternative diagnosis with parasitic, bacterial, fungal or viral pathogens must be considered and treated as early as possible to improve the outcome. Severe patients should be treated empirically with broad spectrum antibacterial drugs and antimalarial molecules according to the local epidemiology.

In 2000, the Saudi Arabian Ministry of Health evaluated the feasibility of a randomized, placebo-controlled trial using intravenous ribavirin in patients with suspected severe RVF, but no official result was published. In a WHO report of the Emerging and Dangerous Pathogens Laboratory Network in 2016, it was briefly mentioned that ribavirin was used without efficacy in Saudi Arabia [101]. Evidence suggests ribavirin efficacy in animal models [102, 103], but it failed to prevent from neuropathology in mice infected by RVFV by aerosol exposure [75]. Ribavirin is recommended for the treatment and the prophylaxis of hemorrhagic fever due to arenaviruses and bunyaviruses [104] and was successfully used to cure and prevent from Lassa fever [105]. To date, its use is not indicated when RVF diagnosis is confirmed $[39,56]$. Antiviral drugs are under development including favipiravir T-705, 2'-fluoro-2'-deoxycytidine ( $2^{\prime}$-FdC), and benzavir-2 [106-109]. Molecules targeting viral components, host cellular components or pathways, such as the ubiquitin proteasome system, autophagy system, kinases and oxidative stress responses, have demonstrated in vitro efficacy against RVFV [110]. The use of polyclonal immunoglobulins or serum of recovered patients has not been reported. Specific monoclonal neutralizing antibodies could be developed in the coming years [111].

To date, liver transplantation has never been attempted in RVFV fulminant hepatitis. In case reports of encephalitis, the use of amantadine, rifampicin, and dexamethasone [72], doubled prednisone doses with a stop in immunosuppressive drugs [74], and phenytoin [70] were reported but not evaluated precisely. Early renal substitution therapy in patients with severe acute renal failure improve the prognosis and survival $[39,56,81]$. For eye involvement, artificial tear preparations may maintain corneal lubrication and provide temporary comfort for ocular irritation. Topical ophthalmic steroids were used in the RVFV anterior segment manifestations [84]. Aciclovir was used in eyes lesions of other mosquito-transmitted viral disease notably chikungunya, dengue and West Nile (Table 2) [112]. Other antiviral drugs (e.g. ganciclovir, foscarnet) could be administrated through intravitreal routes. In case of elevated intraocular pressure, antiglaucoma medications could be useful. Ocular surgery including cataract removal, retinal hole and detachment repair, vitrectomy, and laser ablation for neovascularization could be additional therapeutics to be evaluated.

\section{Algorithm proposal for the management of RVF cases based on their severity and complications}

Based on the clinical and biological scoring system for the prognosis of RVF established by Adam et al. [64], the CDC definitions of suspected severe RVF cases during the major epidemic in Saudi Arabia in 2000 [42], the updated guidelines for health workers [39], and clinical 
series in literature $[19,40,43,45,47,61,63]$, we propose an algorithm to help clinicians at the bedside in the classification and referral of patients during a RVF outbreak (Fig. 4). Using the dengue model for case management, we identified clinical and biological warning signs defining complicated cases at risk of severe illness and requiring hospitalization for medical supervision, as we already proposed for chikungunya [113]. Severe illness included hemorrhagic fever, neurological disorders or hepatic/ renal failures requiring intensive cares. Ocular signs were classified as complications. Ophthalmologic examination should be prospectively performed in all confirmed cases to detect early asymptomatic RVFV ocular signs and evaluate their potential ability to predict the occurrence of neuro-ophthalmologic complications. This should at least include visual acuity determination, intra-ocular pressure measurement, slit-lamp biomicroscopy and funduscopy by indirect ophthalmoscopy. In case of RVF signs, a fluorescein angiography should be performed as well as fundus photography if available. Indocyanine Green angiography has not been evaluated yet in FVR ocular manifestation but could possibly bring arguments for a choroidal involvement since a delayed peripapillary choroidal filling in the arteriovenous phase of fluorescein angiography has been described [38, 85]. Optic Coherence Tomography (OCT) is a recent technique that is yet to be evaluated in the retinal complications of RVF. OCT could be helpful to describe the retinal lesions and their evolution through time, and could help elucidate the nature of the macular exudate-like lesions described before [114]. We recommend to follow-up RVF patients for at least 1 month after the onset of symptoms to monitor for possible delayed neurological and/or ocular complications. In the lack of adequate medical support, considering the diversity and time course of RVF complications, medical evacuation of confirmed cases may be considered, except if hemorrhages because this presentation is a highly contagious vital emergency.

\section{Conclusion}

Rift Valley Fever has emerged and extended outside Africa in the 2000s, leading to the re-description of the human disease. There is a global concern about the risk of RVFV exportation in areas where competent vectors are present including Europe and North America. Economic losses, human morbidity and mortality may be significant during epidemics. Infection with RVF has a wide clinical spectrum and may result in delayed complications. There are no commercially licensed vaccines nor antiviral treatment for humans. Human cases are often detected when the virus has already spread among livestock and people, hence outbreak control is challenging. Thus, human case surveillance systems for early detection and correct management are essential to reduce global morbidity and mortality. We proposed a tool for physician guidance on the field. This algorithm should be evaluated during

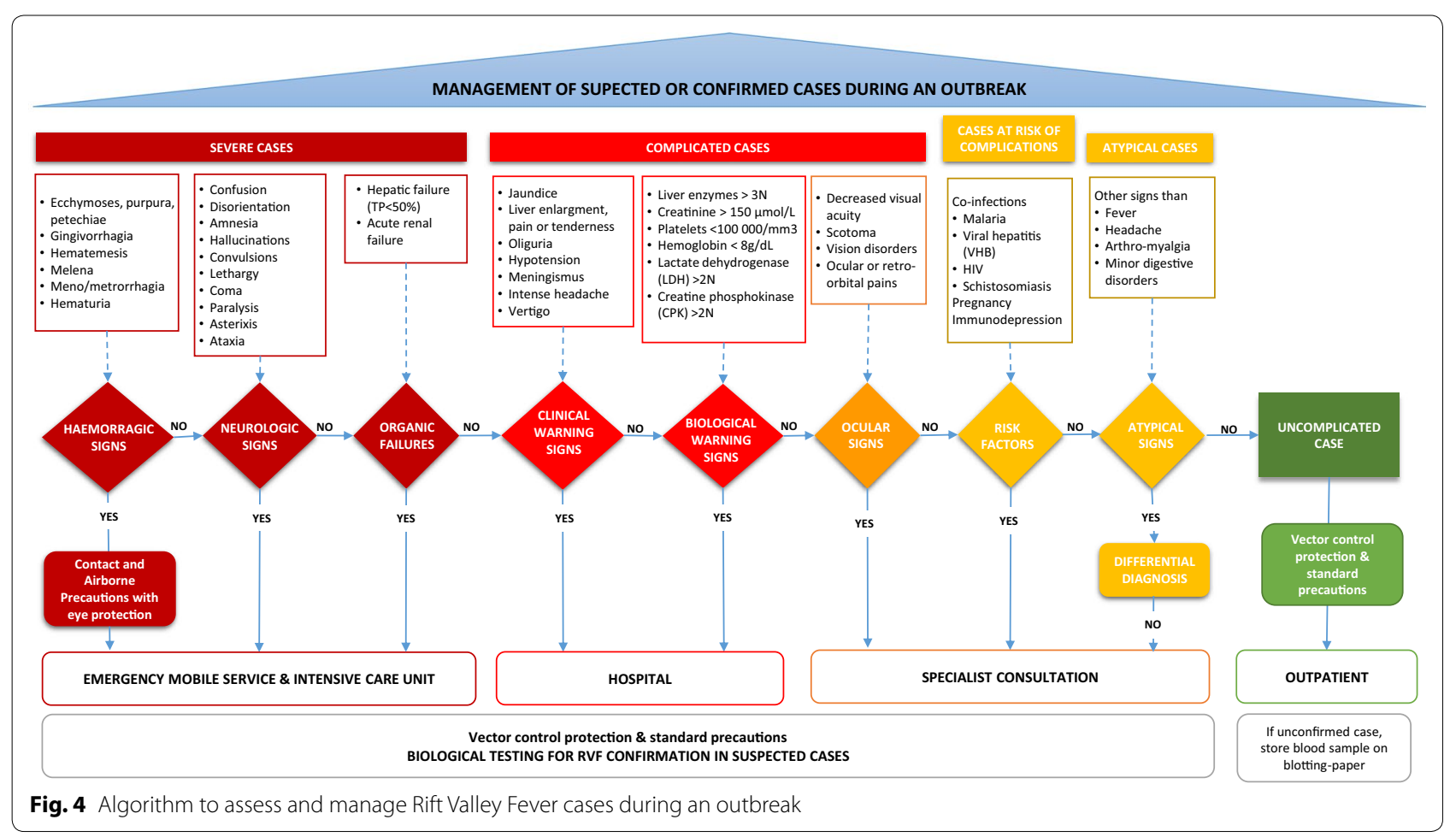


ongoing and coming outbreaks, and could help neighboring places in the detection of cases. We identified frontiers of knowledge and remaining uncertainties concerning RVF which deserves more interest. In particular, therapeutic trials on specific supportive care, antiviral molecules or immunotherapies, should be anticipated to be implemented at the start of future epidemics.

\begin{abstract}
Abbreviations
ADAMTS13: a disintegrin and metalloproteinase with thrombospondin motifs; ARN: acute retinal necrosis; ASPPC: acute syphilitic posterior placoid chorioretinopathy; BSL: biosafety level; CDC: Center for Disease Control and Prevention; $\mathrm{Cl}$ : confidence interval; CMV: cytomegalovirus; CRP: $\mathrm{C}$ reactive protein; CSF: cerebrospinal fluid; CT-scan: computed tomography scan; EBV: Epstein Barr virus; ELISA: enzyme-linked immunosorbent assay; HIV: human immunodeficiency virus; HSV: herpes simplex viruses; HVFs: hemorrhagic viral fevers; Ig: immunoglobulin; IPC: infection prevention and control; IP-10: interferon-y induced protein; MAVS: mitochondrial antiviral signaling protein; MCP-2: monocyte chemottractant protein; MRI: magnetic resonance imaging; MyD88: myeloid differentiation; OCT: optic coherence tomography; ONH: optic nerve hypoplasia; PPE: Personal Protective Equipment; PORN: progressive outer retinal necrosis; qRT-PCR: quantitative reverse transcription polymerase chain reaction; RIG-I: retinoic acid-inducible gene; RNA: ribonucleic acid; RPE: retinal pigment epithelium; RVF: Rift Valley Fever; RVFV: Rift Valley Fever virus; sICAM-1: soluble intracellular adhesion molecule; SSPE: subacute sclerosing panencephalitis; TLR8: toll-like receptor; tPA: tissue plasminogen activator; TRIF: TIR-domain-containing adapter-inducing interferon-B; VZV: varicella zoster virus; WHO: World Health Organization.
\end{abstract}

\section{Acknowledgements}

The authors are very thankful to Julien Ripamonti for his precious help in figures.

\section{Authors' contributions}

EJ made the literature review and wrote the first draft. AL made literature review and wrote the draft on ocular diseases and built Table 2. GH reviewed and corrected the ophthalmological part of the draft. VPS, FL, GT are the epidemiologists involved in the response to RVF cases in soldiers in Mayotte, they provided epidemiological data, asked for questions to clinicians and reviewed the draft. TL was the French military physicians deployed in Mayotte who was at the origin of this work. GD and ILG from the French National Reference center for Arboviruses, confirmed cases in Mayotte and helped in the discussion and the draft for the biological part. FS is national referent in infectious diseases for the French Armed Forces; he managed the working group, helped in the selection of references and the algorithm development. He reviewed and corrected the draft. All authors read and approved the final manuscript.

\section{Funding}

Authors did not receive any funding for this work.

\section{Availability of data and materials}

Not applicable.

\section{Ethics approval and consent to participate}

Not applicable.

\section{Consent for publication}

Not applicable.

\section{Competing interests}

The authors declare that the research was conducted in the absence of any commercial or financial relationships that could be construed as potential competing interests.

\section{Author details}

${ }^{1}$ Laveran Military Teaching Hospital, CS500413384, Marseille Cedex 13, France.

${ }^{2}$ IRD, AP-HM, SSA, VITROME, IHU-Méditerranée Infection, Aix Marseille Univ,
Marseille, France. ${ }^{3}$ French Armed Forces Centre for Epidemiology and Public Health (CESPA), Marseille, France. ${ }^{4}$ INSERM, IRD, SESSTIM, Sciences Economiques \& Sociales de la Santé \& Traitement de I'Information Médicale, Aix Marseille Univ, Marseille, France. ${ }^{5}$ French Military Health Service, RSMA Medical Unit, Paris, Mayotte, France. ${ }^{6}$ French Armed Forces Biomedical Research Institute (IRBA)-CNR des arbovirus-IHU Méditerranée Infection, Marseille, France. ${ }^{7}$ IRD 190, Inserm 1207, IHU Méditerranée Infection, AP-HM, UVE, AixMarseille Univ, Marseille, France.

Received: 18 July 2019 Accepted: 12 January 2020

Published online: 22 January 2020

\section{References}

1. Daubney R, Hudson JR, Garnham PC. Enzootic hepatitis or rift valley fever. An undescribed virus disease of sheep cattle and man from east Africa. J Pathol Bacteriol. 1931:34:545-79.

2. Tantely LM, Boyer S, Fontenille D. A review of mosquitoes associated with Rift Valley fever virus in Madagascar. Am J Trop Med Hyg. 2015;92:722-9.

3. Monaco F, Pinoni C, Cosseddu GM, Khaiseb S, Calistri P, Molini U, et al. Rift Valley fever in Namibia, 2010. Emerging Infect Dis. 2013;19:2025-7.

4. Hartman A. Rift Valley Fever. Clin Lab Med. 2017;37:285-301.

5. Wright D, Kortekaas J, Bowden TA, Warimwe GM. Rift Valley fever: biology and epidemiology. J Gen Virol. 2019;100:1187-99.

6. Centers for Disease Control (CDC). Biosafety in Microbiological and Biomedical Laboratories (BMBL), 5th Edn. CDC Laboratory Portal; 2018. https://www.cdc.gov/labs/BMBL.html. Accessed 27 June 2019.

7. Martinet J-P, Ferté H, Failloux A-B, Schaffner F, Depaquit J. Mosquitoes of North-Western Europe as potential vectors of arboviruses: a review. Viruses. 2019;11:E1059.

8. Pepin M, Bouloy M, Bird BH, Kemp A, Paweska J. Rift Valley fever virus (Bunyaviridae: Phlebovirus): an update on pathogenesis, molecular epidemiology, vectors, diagnostics and prevention. Vet Res. 2010;41:61.

9. Tong C, Javelle E, Grard G, Dia A, Lacrosse C, Fourié T, et al. Tracking Rift Valley fever: from Mali to Europe and other countries, 2016. Eurosurveillance. 2019;24:1800213.

10. Chevalier V. Relevance of Rift Valley fever to public health in the European Union. Clin Microbiol Infect. 2013;19:705-8.

11. Liu J, Sun Y, Shi W, Tan S, Pan Y, Cui S, et al. The first imported case of Rift Valley fever in China reveals a genetic reassortment of different viral lineages. Emerg Microbes Infect. 2017;6:e4.

12. Wiwanitkit S. Emerging Rift Valley fever in China: what should be known? Asian Pac J Trop Biomed. 2016;6(9):727-9.

13. Lumley S, Hernández-Triana LM, Horton DL, Fernández de Marco MDM Medlock JM, Hewson R, et al. Competence of mosquitoes native to the United Kingdom to support replication and transmission of Rift Valley fever virus. Parasite Vectors. 2018;11:308.

14. Hartley DM, Rinderknecht JL, Nipp TL, Clarke NP, Snowder GD, National Center for Foreign Animal and Zoonotic Disease Defense Advisory Group on Rift Valley Fever. Potential effects of Rift Valley fever in the United States. Emerging Infect Dis. 2011;17:e1.

15. Hartman DA, Rice LM, DeMaria J, Borland EM, Bergren NA, Fagre AC, et al. Entomological risk factors for potential transmission of Rift Valley fever virus around concentrations of livestock in Colorado. Transbound Emerg Dis. 2019:66:1709-17.

16. Dar O, Mclntyre S, Hogarth S, Heymann D. Rift Valley fever and a new paradigm of research and development for zoonotic disease control. Emerging Infect Dis. 2013;19:189-93.

17. Laughlin LW, Meegan JM, Strausbaugh LJ, Morens DM, Watten RH. Epidemic Rift Valley fever in Egypt: observations of the spectrum of human illness. Trans R Soc Trop Med Hyg. 1979;73:630-3.

18. Ahmad K. More deaths from Rift Valley fever in Saudi Arabia and Yemen. Lancet. 2000;356:1422.

19. Mohamed M, Mosha F, Mghamba J, Zaki SR, Shieh W-J, Paweska J, et al. Epidemiologic and clinical aspects of a Rift Valley fever outbreak in humans in Tanzania, 2007. Am J Trop Med Hyg. 2010;83:22-7.

20. Bourée P. Rift Valley Fever: new outbreak in Mayotte. Bull Soc Pathol Exot. 2019;112:153-5. 
21. Himeidan YE, Kweka EJ, Mahgoub MM, El Rayah EA, Ouma JO. Recent outbreaks of Rift Valley Fever in East Africa and the Middle East. Front Public Health. 2014;2:169.

22. Moher D, Shamseer L, Clarke M, Ghersi D, Liberati A, Petticrew M, et al. Preferred reporting items for systematic review and meta-analysis protocols (PRISMA-P) 2015 statement. Syst Rev. 2015;2015:4.

23. World Health Organization (WHO). Rift Valley fever. https://www.who. int/news-room/fact-sheets/detail/rift-valley-fever. Accessed 31 Dec 2019.

24. Centers for Disease Control (CDC). Outbreak Summaries Rift Valley Fever. https://www.cdc.gov/vhf/rvf/outbreaks/summaries.html. Accessed 26 June 2019.

25. Nanyingi MO, Munyua P, Kiama SG, Muchemi GM, Thumbi SM, Bitek AO et al. A systematic review of Rift Valley Fever epidemiology 1931-2014. Infect Ecol Epidemiol. 2015;5:28024.

26. Morvan J, Saluzzo JF, Fontenille D, Rollin PE, Coulanges P. Rift Valley fever on the east coast of Madagascar. Res Virol. 1991;142:475-82.

27. Métras R, Cavalerie L, Dommergues L, Mérot P, Edmunds WJ, Keeling MJ, et al. The Epidemiology of Rift Valley Fever in Mayotte: insights and perspectives from 11 years of data. PLoS Negl Trop Dis. 2016;10(6):e0004783.

28. Sissoko D, Giry C, Gabrie P, Tarantola A, Pettinelli F, Collet L, et al. Rift Valley fever, Mayotte, 2007-2008. Emerging Infect Dis. 2009;15:568-70.

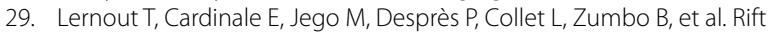
valley fever in humans and animals in Mayotte, an endemic situation? PLOS ONE. 2013;8:e74192.

30. Institut National de Veille Sanitaire (INVS). Fièvre de la Vallée du Rift à Mayotte : point de situation au 24 mai 2019. http://www.ocean-indie n.ars.sante.fr/fievre-de-la-vallee-du-rift-mayotte-point-de-situation-au24-mai-2019. Accessed 26 June 2019.

31. Linfo.re. Fièvre de la Vallée du Rift: 141 cas humains signalés à Mayotte. https://www.linfo.re/ocean-indien/mayotte/fievre-de-la-vallee-du-rift141-cas-humains-signales-a-mayotte. Accessed 9 July 2019.

32. Gaff H, Hartley D, Leahy N. An epidemiological model of Rift Valley Fever. Electron J Diff Eq. 2007;115:1-12.

33. Niu T, Gaff HD, Papelis YE, Hartley DM. An epidemiological model of Rift Valley fever with spatial dynamics. Comput Math Methods Med. 2012:2012:138757.

34. Li J, Blakeley D, Smith RJ. The failure of R0. Comput Math Methods Med. 2011:2011:527610.

35. Ikegami T, Makino S. The pathogenesis of Rift Valley Fever. Viruses. 2011;3:493-519.

36. Pépin $M$, avec la participation de la CIRE Réunion-Mayotte et l'Institut de Veille Sanitaire (InVS). Rift Valley fever. Med Mal Infect. 2011;41:322-9.

37. Abdel-Wahab KS, El Baz LM, El-Tayeb EM, Omar H, Ossman MA, Yasin W. Rift Valley Fever virus infections in Egypt: pathological and virological findings in man. Trans R Soc Trop Med Hyg. 1978;72:392-6.

38. Siam AL, Meegan JM, Gharbawi KF. Rift Valley fever ocular manifestations: observations during the 1977 epidemic in Egypt. Br J Ophthalmol. 1980;64:366-74.

39. Rwanda Biomedical Centre. GUIDELINES ON RIFT VALLEY FEVER Revised 22 June 2018. http://www.rbc.gov.rw/fileadmin/user_upload/ RIFT_VALLEY_FEVER_GUIDELINE Revised_22_June_2018.pdf. Accessed 24 Feb 2019.

40. Madani TA, Al-Mazrou YY, Al-Jeffri MH, Mishkhas AA, Al-Rabeah AM, Turkistani AM, et al. Rift Valley fever epidemic in Saudi Arabia: epidemiological, clinical, and laboratory characteristics. Clin Infect Dis. 2003:37:1084-92.

41. Centers for Disease Control and Prevention (CDC). Rift Valley fever outbreak-Kenya, November 2006-January 2007. MMWR Morb Mortal Wkly Rep. 2007;56:73-6.

42. Centers for Disease Control (CDC). Update: Outbreak of Rift Valley Fever Saudi Arabia, August-November 2000. https://www.cdc.gov/mmwr/ preview/mmwrhtml/mm4943a3.htm. Accessed 29 June 2019.

43. Kahlon SS, Peters CJ, Leduc J, Muchiri EM, Muiruri S, Njenga MK, et al. Severe Rift Valley fever may present with a characteristic clinical syndrome. Am J Trop Med Hyg. 2010;82:371-5.

44. van Velden DJ, Meyer JD, Olivier J, Gear JH, McIntosh B. Rift Valley fever affecting humans in South Africa: a clinicopathological study. S Afr Med J. 1977:51:867-71
45. Boushab MB, Savadogo M, Sow MS, Fall-Malick FZ, Seydi M. Severe hemorrhagic form of Rift Valley Fever in Mauritania. Bull Soc Pathol Exot. 2015:108:102-6.

46. Rakotoarivelo RA, Andrianasolo R, Razafimahefa SH, Randremandranto Razafimbelo NS, Randria MJD. Severe presentations of Rift Valley Fever in Madagascar. Med Mal Infect. 2011;41:318-21.

47. Al-Hazmi M, Ayoola EA, Abdurahman M, Banzal S, Ashraf J, El-Bushra A, et al. Epidemic Rift Valley fever in Saudi Arabia: a clinical study of severe illness in humans. Clin Infect Dis. 2003:36:245-52.

48. Nderitu L, Lee JS, Omolo J, Omulo S, O'Guinn ML, Hightower A, et al. Sequential Rift Valley fever outbreaks in eastern Africa caused by multiple lineages of the virus. J Infect Dis. 2011;203:655-65.

49. Baba M, Masiga DK, Sang R, Villinger J. Has Rift Valley fever virus evolved with increasing severity in human populations in East Africa? Emerg Microbes Infect. 2016;5:e58.

50. Morrill JC, Ikegami T, Yoshikawa-Iwata N, Lokugamage N, Won S, Terasaki K, et al. Rapid accumulation of virulent rift valley Fever virus in mice from an attenuated virus carrying a single nucleotide substitution in the m RNA. PLOS ONE. 2010;5:e9986.

51. Bird BH, Khristova ML, Rollin PE, Ksiazek TG, Nichol ST. Complete genome analysis of 33 ecologically and biologically diverse Rift Valley Fever virus strains reveals widespread virus movement and low genetic diversity due to recent common ancestry. J Virol. 2007;81:2805-16.

52. Bird BH, McElroy AK. Rift Valley fever virus: unanswered questions. Antiviral Res. 2016:132:274-80.

53. LaBeaud AD, Pfeil S, Muiruri S, Dahir S, Sutherland LJ, Traylor Z, et al. Factors associated with severe human Rift Valley fever in Sangailu, Garissa County, Kenya. PLoS Negl Trop Dis. 2015;9:e0003548.

54. Njenga MK, Paweska J, Wanjala R, Rao CY, Weiner M, Omballa V, et al. Using a field quantitative real-time PCR test to rapidly identify highly viremic rift valley fever cases. J Clin Microbiol. 2009:47:1166-71.

55. Hise AG, Traylor Z, Hall NB, Sutherland LJ, Dahir S, Ermler ME, et al. Association of symptoms and severity of rift valley fever with genetic polymorphisms in human innate immune pathways. PLoS Negl Trop Dis. 2015:9:e0003584.

56. Paweska JT. Rift Valley Fever. Rev Sci Tech Off Int Epiz. 2015;34:375-89.

57. Smith DR, Steele KE, Shamblin J, Honko A, Johnson J, Reed C, et al. The pathogenesis of Rift Valley fever virus in the mouse model. Virology. 2010;407:256-67.

58. Ayoola AE, Al-Hazmi MH, Michail NT, Aderoju A, Hafez MM, Banzal SB. Liver involvement in patients with moderately severe rift valley fever. The American Journal of Gastroenterology. 2003;98:592.

59. Shraim MA, Eid R, Radad K, Saeed N. Ultrastructural pathology of human liver in Rift Valley fever. BMJ Case Rep. 2016. https://doi. org/10.1136/bcr-2016-216054.

60. Shieh W-J, Paddock CD, Lederman E, Rao CY, Gould LH, Mohamed M, et al. Pathologic studies on suspect animal and human cases of Rift Valley fever from an outbreak in Eastern Africa, 2006-2007. Am J Trop Med Hyg. 2010;83:38-42.

61. Boushab BM, Fall-Malick FZ, Ould Baba SEW, Ould Salem ML, Belizaire MRD, Ledib H, et al. Severe human illness caused by Rift Valley Fever Virus in Mauritania, 2015. Open Forum Infect Dis. 2016;3:200.

62. Philippe B, Jouan A, Riou O, Coulibaly I, Lequenno B, Meegan J, et al. Hemorrhagic forms of Rift Valley fever in Mauritania. Bull Soc Pathol Exot. 1989:82:611-9.

63. Strausbaugh LJ, Laughlin LW, Meegan JM, Watten RH. Clinical studies on Rift Valley fever, Part I: acute febrile and hemorrhagic-like diseases. J Egypt Public Health Assoc. 1978;53:181-2.

64. Adam F, Jouan A, Riou O, Philippe B, Coulibaly I, Berlioz B, et al. Development of a clinical and biological scoring system for the prognosis of Rift Valley fever. Bull Soc Pathol Exot. 1989;82:628-36.

65. Jouan A, Philippe B, Riou O, Coulibaly I, Leguenno B, Meegan J, et al. Mild clinical forms of Rift Valley fever during the epidemic in Mauritania. Bull Soc Pathol Exot. 1989;82:620-7.

66. Al-Khuwaitir TS, Al-Moghairi AM, Sherbeeni SM, AI-Ghamdi AS. Rift Valley fever hepatitis complicated by disseminated intravascular coagulation and hepatorenal syndrome. Saudi Med J. 2004;25:528-31.

67. Anyangu AS, Gould LH, Sharif SK, Nguku PM, Omolo JO, Mutonga D, et al. Risk factors for severe Rift Valley fever infection in Kenya, 2007. Am J Trop Med Hyg. 2010;83:14-21. 
68. Salem MLO, Baba SEWO, Fall-Malick FZ, Boushab BM, Ghaber SM, Mokhtar A. Severe hemorrhagic forms of Rift Valley fever: about 5 cases. Pan Afr Med J. 2016:24:73.

69. De St Maurice A, Harmon J, Nyakarahuka L, Balinandi S, Tumusiime A, Kyondo J, et al. Rift valley fever viral load correlates with the human inflammatory response and coagulation pathway abnormalities in humans with hemorrhagic manifestations. PLoS Negl Trop Dis. 2018;12:e0006460.

70. Alrajhi AA, Al-Semari A, Al-Watban J. Rift Valley fever encephalitis. Emerging Infect Dis. 2004;10:554-5.

71. Riou O, Philippe B, Jouan A, Coulibaly I, Mondo M, Digoutte JP. Neurologic and neurosensory forms of Rift Valley fever in Mauritania. Bull Soc Pathol Exot. 1989;82:605-10.

72. Maar SA, Swanepoel R, Gelfand M. Rift Valley fever encephalitis. A description of a case. Cent Afr J Med. 1979;25:8-11.

73. Laughlin LW, Girgis NI, Meegan JM, Strausbaugh LJ, Yassin MW, Watten $\mathrm{RH}$. Clinical studies on Rift Valley fever. Part 2: Ophthalmologic and central nervous system complications. J Egypt Public Health Assoc. 1978;53:183-4.

74. Haneche F, Leparc-Goffart I, Simon F, Hentzien M, Martinez-Pourcher $V$, Caumes $E$, et al. Rift Valley fever in kidney transplant recipient returning from Mali with viral RNA detected in semen up to four months from symptom onset, France, autumn 2015. Eurosurveillance. 2016. https://doi.org/10.2807/1560-7917.ES.2016.21.18.30222

75. Reed C, Lin K, Wilhelmsen C, Friedrich B, Nalca A, Keeney A, et al. Aerosol exposure to Rift Valley fever virus causes earlier and more severe neuropathology in the murine model, which has important implications for therapeutic development. PLoS Negl Trop Dis. 2013;7:e2156

76. Hartman AL, Powell DS, Bethel LM, Caroline AL, Schmid RJ, Oury T, et al. Aerosolized rift valley fever virus causes fatal encephalitis in african green monkeys and common marmosets. J Virol. 2014;88:2235-45.

77. Wiley CA, Bhardwaj N, Ross TM, Bissel SJ. Emerging infections of CNS: avian influenza A virus, Rift Valley Fever Virus and human parechovirus. Brain Pathol. 2015:25:634-50

78. Albe JR, Boyles DA, Walters AW, Kujawa MR, McMillen CM, Reed DS, et al. Neutrophil and macrophage influx into the central nervous system are inflammatory components of lethal Rift Valley fever encephalitis in rats. PLoS Pathog. 2019;15:e1007833.

79. Wonderlich ER, Caroline AL, McMillen CM, Walters AW, Reed DS, Barratt-Boyes SM, et al. Peripheral blood biomarkers of disease outcome in a monkey Model of Rift Valley Fever encephalitis. J Virol. 2018;92:e01662-17.

80. Walters AW, Kujawa MR, Albe JR, Reed DS, Klimstra WB, Hartman AL. Vascular permeability in the brain is a late pathogenic event during Rift Valley fever virus encephalitis in rats. Virology. 2019;526:173-9.

81. El Imam M, El Sabiq M, Omran M, Abdalkareem A, El Gaili Mohamed MA, Elbashir A, et al. Acute renal failure associated with the Rift Valley fever: a single center study. Saudi J Kidney Dis Transpl. 2009:20:1047-52

82. Freed I. Rift valley fever in man, complicated by retinal changes and loss of vision. S Afr Med J. 1951:25:930-2.

83. Schrire L. Macular changes in rift valley fever. S Afr Med J. 1951;25:926-30.

84. Al-Hazmi A, Al-Rajhi AA, Abboud EB, Ayoola EA, Al-Hazmi M, Saadi $\mathrm{R}$, et al. Ocular complications of Rift Valley fever outbreak in Saudi Arabia. Ophthalmology. 2005;112:313-8.

85. Yoser SL, Forster DJ, Rao NA. Systemic viral infections and their retinal and choroidal manifestations. Surv Ophthalmol. 1993;37:313-52.

86. Newman-Gerhardt S, Muiruri S, Muchiri E, Peters CJ, Morrill J, Lucas $\mathrm{AH}$, et al. Potential for autoimmune pathogenesis of Rift Valley Fever virus retinitis. Am J Trop Med Hyg. 2013;89:495-7.

87. Ranjan R, Ranjan S. Ocular pathology: role of emerging viruses in the Asia-Pacific Region-A review. Asia-Pac J Ophthalmol. 2014;3:299-307.

88. Khairallah M, Ladjimi A, Chakroun M, Messaoud R, Yahia SB, Zaouali S, et al. Posterior segment manifestations of Rickettsia conorii infection. Ophthalmology. 2004;111:529-34.

89. Khairallah M, Kahloun R, Ben Yahia S, Jelliti B, Messaoud R. New infectious etiologies for posterior uveitis. Ophthalmic Res. 2013;49:66-72.
90. Galindo-Cardiel I, Busquets N, Velarde R, Abad FX, Solanes D, Rivas R, et al. Lymphoplasmacytic endotheliitis and anterior uveitis in sheep infected experimentally with rift valley fever virus. J Comp Pathol. 2012;146:40-3

91. Niklasson B, Liljestrand J, Bergström S, Peters CJ. Rift Valley fever: a sero-epidemiological survey among pregnant women in Mozambique. Epidemiol Infect. 1987;99:517-22.

92. Abdel-Aziz AA, Meegan JM, Laughlin LW. Rift Valley fever as a possible cause of human abortions. Trans R Soc Trop Med Hyg. 1980;74:685-6.

93. Baudin M, Jumaa AM, Jomma HJE, Karsany MS, Bucht G, Näslund J, et al. Association of Rift Valley fever virus infection with miscarriage in Sudanese women: a cross-sectional study. Lancet Glob Health. 2016:4:e864-71.

94. Adam I, Karsany MS. Case report: Rift Valley Fever with vertical transmission in a pregnant Sudanese woman. J Med Virol. 2008;80:929.

95. Arishi HM, Aqeel AY, Al Hazmi MM. Vertical transmission of fatal Rift Valley fever in a newborn. Ann Trop Paediatr. 2006:26:251-3.

96. Woods CW, Karpati AM, Grein T, McCarthy N, Gaturuku P, Muchiri E, et al. An outbreak of Rift Valley Fever in Northeastern Kenya, 1997-98. Emerg Infect Dis. 2002;8:138-44.

97. Al Azraqi TA, El Mekki AA, Mahfouz AA. Rift Valley fever among children and adolescents in southwestern Saudi Arabia. J Infect Public Health. 2013;6:230-5.

98. Centers for Disease Control (CDC). Isolation precautions. Guidelines library. Infection Control. https://www.cdc.gov/infectioncontrol/ guidelines/isolation/index.html. Accessed 30 June 2019.

99. Al-Hamdan NA, Panackal AA, Al Bassam TH, Alrabea A, Al Hazmi M, Al Mazroa Y, et al. The risk of nosocomial transmission of Rift Valley Fever. PLoS Negl Trop Dis. 2015;9:e0004314.

100. World Health Organization (WHO). Standard precautions in health care 2007. https://www.who.int/csr/resources/publications/EPR_ AM2 E7.pdf. Accessed 30 June 2019.

101. World Health Organization (WHO). Emerging and Dangerous Pathogens Laboratory Network (EDPLN). Fièvre de la vallée du Rift en Afrique: aspects cliniques chez l'homme. https://studylibfr.com/ doc/1012718/fièvre-de-la-vallée-du-rift-en-afrique-aspects-clini ques. Accessed 30 June 2019.

102. Kende M, Alving CR, Rill WL, Swartz GM, Canonico PG. Enhanced efficacy of liposome-encapsulated ribavirin against Rift Valley fever virus infection in mice. Antimicrob Agents Chemother. 1985;27:903-7.

103. Huggins JW. Prospects for treatment of viral hemorrhagic fevers with ribavirin, a broad-spectrum antiviral drug. Rev Infect Dis. 1989;11(Suppl 4):S750-61.

104. Bossi P, Tegnell A, Baka A, Van Loock F, Hendriks J, Werner A, et al. Bichat guidelines for the clinical management of haemorrhagic fever viruses and bioterrorism-related haemorrhagic fever viruses. Eurosurveillance. 2004;9:E11-2.

105. Bausch DG, Hadi CM, Khan SH, Lertora JJL. Review of the literature and proposed guidelines for the use of oral ribavirin as postexposure prophylaxis for Lassa fever. Clin Infect Dis. 2010:51:1435-41.

106. Islam MK, Strand M, Saleeb M, Svensson R, Baranczewski P, Artursson $P$, et al. Anti-Rift Valley fever virus activity in vitro, pre-clinical pharmacokinetics and oral bioavailability of benzavir-2, a broad-acting antiviral compound. Sci Rep. 2018:8:1925.

107. Scharton D, Bailey KW, Vest Z, Westover JB, Kumaki Y, Van Wettere A, et al. Favipiravir (T-705) protects against peracute Rift Valley fever virus infection and reduces delayed-onset neurologic disease observed with ribavirin treatment. Antiviral Res. 2014;104:84-92.

108. Smee DF, Jung K-H, Westover J, Gowen BB. 2'-Fluoro-2'-deoxycytidine is a broad-spectrum inhibitor of bunyaviruses in vitro and in phleboviral disease mouse models. Antiviral Res. 2018;160:48-54.

109. Borrego B, de Ávila Al, Domingo E, Brun A. Lethal mutagenesis of Rift Valley Fever Virus induced by favipiravir. Antimicrob Agents Chemother. 2019;63:e00669-19.

110. Atkins $C$, Freiberg AN. Recent advances in the development of antiviral therapeutics for Rift Valley fever virus infection. Future Virol. 2017;12:651-65.

111. Allen ER, Krumm SA, Raghwani J, Halldorsson S, Elliott A, Graham VA, et al. A protective monoclonal antibody targets a site 
of vulnerability on the surface of Rift Valley Fever Virus. Cell Rep. 2018;25(3750-3758):e4.

112. Karesh JW, Mazzoli RA, Heintz SK. Ocular manifestations of mosquitotransmitted diseases. Mil Med. 2018;183:450-8.

113. Simon F, Javelle E, Cabie A, Bouquillard E, Troisgros O, Gentile G, et al. French guidelines for the management of chikungunya (acute and persistent presentations). Med Mal Infect. 2015;45:243-63.

114. Hassan MM, Agarwal A, Afridi RM, daSilva MJB, Karaca I, Sadiq MA, et al. The role of optical coherence tomography angiography in the management of uveitis. Int Ophthalmol Clin Fall. 2016;2016(56):1-24.

\section{Publisher's Note}

Springer Nature remains neutral with regard to jurisdictional claims in published maps and institutional affiliations.
Ready to submit your research? Choose BMC and benefit from:

- fast, convenient online submission

- thorough peer review by experienced researchers in your field

- rapid publication on acceptance

- support for research data, including large and complex data types

- gold Open Access which fosters wider collaboration and increased citations

- maximum visibility for your research: over $100 \mathrm{M}$ website views per year

At BMC, research is always in progress.

Learn more biomedcentral.com/submissions 